\title{
DRYING OF HERBAGE SAMPLES FOR ANALYSES
}

\author{
Majja-Liisa Salo and Kaija Kotilainen \\ Department of Animal Husbandry, University of Helsinki
}

Received 16. 1. 1970

The majority of the methods applied in the analysis of herbage samples relates to dried substrates. However, the method of drying may alter the sample composition to such an extent that erroneous results are arrived at in analyses.

Several workers propose freeze drying as the most suitable method of preparing plant material for chemical analyses (Davies et al. 1948, Bathurst et al. 1949). Hofman (1965) and Jones and GRIFFrTH (1968) have recently suggested microwave heating as a method of drying herbage samples.

In the authors' experience, vacuum drying at $40^{\circ} \mathrm{C}$ is as good a method as freeze drying one and that is technically easier to perform (SALO 1965b). With some materials the temperature can be even raised somewhat above $40^{\circ} \mathrm{C}$ without inducing the decomposition of sugars.

Observations made in the authors' practical work imply that a high drying temperature causes errors not only in the determination of sugars, but also in the estimation of substances determined as an insoluble residue. According to van Soest (1964), heat damage occurs in drying at a temperature higher than $50^{\circ} \mathrm{C}$. This effect involves the non-enzymic browning reaction which is catalyzed by moisture.

The main purpose of the present investigation was to find out how a herbage sample can be dried in a common oven without inducing sugar losses. The importance of the sugars has been recently emphasized in conjunction with both the feeding of milk cows and the preparation of silage, hence sugar determinations are being carried out in the rather simply equipped laboratories of various experiment stations, where an oven is the only means of drying. An investigation is thus essential for just these conditions.

Secondly, the investigation was made with a view to clarifying to what extent a high temperature and the other factors relating to the drying would cause errors in the determinations of the substances as an insoluble residue. The criterions in this respect were lignin and crude fibre. Also the crude protein was determined. 


\section{Materials and methods}

M a t e ri a l s. The herbage samples were chopped or ground, mixed thoroughly and placed into the drying equipment. The food and faeces samples were ground in a Wiley mill using sieve No. 40.

The mixtures used in the tests were prepared from pure substances; the compositions are listed in Table 4. The water-soluble substances were dissolved in water, and the dry materials were added to the solution. The dried mixtures were ground in an IKA mill.

$\mathrm{M}$ e $\mathrm{th}$ o d s. The total amount of the sugars was determined according to SALO (1965a) as follows. The sugars were extracted and hydrolysed from $0.5 \mathrm{~g}$ or $1 \mathrm{~g}$ samples, by treating them with $0.1 \mathrm{~N}$ hydrochloric acid at $40^{\circ} \mathrm{C}$ for 20 hours. The hydrolysate was filtered through filter paper into a measuring flask, a small proportion of the filtrate was purified by ion-exchangers using a batch-technique, and the reducing sugars determined.

The crude lignin was determined as follows. An $1 \mathrm{~g}$ sample was extracted for 5 hours with $80-\%$ ethanol in a Soxhlet apparatus. The dried sample was kept for 20 hours at $40^{\circ} \mathrm{C}$ in $0.1 \mathrm{~N}$ hydrochloric acid containing $0.1 \%$ of pepsin, and then filtered through filter paper. The insoluble residue was refluxed for 2 hours in $1 \mathrm{~N}$ sulphuric acid, and the resulting mixture filtered through filter paper. The dry residue was subjected to a hydrolytic treatment in $72 \% \mathrm{H}_{2} \mathrm{SO}_{4}\left(5 \mathrm{ml}, 20^{\circ} \mathrm{C}, 4 \mathrm{~h}\right)$, the solution was diluted with water to $1 \mathrm{~N}$, and then refluxed for 1 hour. After filtration through a Gooch asbestos crucible, the loss on ignition was determined. In some tests the nitrogen content of the crude lignin was determined from a similarly treated second sample, and a proteincorrection was made $(6.25 \times \mathrm{N})$.

The crude fibre content was determined by the conventional method.

The crude protein was determined according to the Kjeldahl method.

\section{Results and discussion}

Experiment with herbage samples. Tables 1 and 2 present the results of the drying of thin and somewhat thicker layers, respectively. Only in some cases was the thickness of the layer accurately determined; in the beginning of the test series this detail was assumed not to affect the results. Only the inspection of the results revealed that this was not the case. Naturally more 'attractive' Tables would have been obtained if the tests had been repeated using strictly defined layer thicknesses. This was not done, however, since the effect had been established clearly enough. Moreover, a similar observation had been made by van SoEsT (1964) in connection with the heat-drying of herbage samples.

The results presented in Tables 1 and 2 confirm the previous observations showing that equal sugar values are obtained in vacuum drying at $40^{\circ} \mathrm{C}$, and freeze drying (SALO $1965 \mathrm{~b})$. In this case the thickness of the sample layer has not influenced the result. Technically, vacuum drying offers in several respects advantages over freeze drying. The freeze dryer is expensive and, moreover, low in capacity when a large number of samples have to be dried at the same time. On the other hand, vacuum drying can be performed with even a large number of samples. Furthermore, in comparison with a freeze dried sample, a sample dried at $40^{\circ} \mathrm{C}$ is more easily handled in the various stages of the analytical processes, for example in grinding and filtration. 
Table 1. Effect of temperature on thin layer drying. Figures are percentages of dry matter.

\begin{tabular}{|c|c|c|c|c|c|c|}
\hline Material & $\begin{array}{l}\text { Drying procedure } \\
\text { Temperature }{ }^{\circ} \mathrm{C}\end{array}$ & & Sugars & $\begin{array}{l}\text { Crude } \\
\text { lignin }\end{array}$ & $\begin{array}{l}\text { Crude } \\
\text { fibre }\end{array}$ & $\begin{array}{l}\text { Crude } \\
\text { protein }\end{array}$ \\
\hline \multirow[t]{4}{*}{ Cabbage } & Vacuum at $40^{\circ}$ & & 56.5 & 0.2 & 8.6 & 10.7 \\
\hline & Oven at $100^{\circ}$ & $60 \mathrm{~min} .+$ at $50^{\circ}$ & 56.5 & 0.4 & 8.6 & 10.7 \\
\hline & $\Rightarrow \quad 65^{\circ}$ & & 51.7 & 0.3 & 8.7 & 10.9 \\
\hline & $100^{\circ}$ & & 31.9 & 1.1 & 12.1 & 11.1 \\
\hline \multirow[t]{5}{*}{ Swede I } & Vacuum at $40^{\circ}$ & & 55.0 & 0.5 & 12.1 & 9.2 \\
\hline & Oven at $100^{\circ}$ & $60 \mathrm{~min} .+$ at $50^{\circ}$ & 55.3 & 0.6 & 12.2 & 9.3 \\
\hline & $\Rightarrow \quad 65^{\circ}$ & & 51.6 & 0.6 & 12.0 & 9.1 \\
\hline & $100^{\circ}$ & & 36.4 & 0.9 & 14.3 & 9.0 \\
\hline & $107^{\circ}$ & & 32.5 & 1.2 & 14.8 & 9.1 \\
\hline \multirow{4}{*}{$\begin{array}{l}\text { Meadow fescue, } \\
\text { leaf stage }\end{array}$} & Freeze drying & & 17.3 & 1.8 & 21.3 & 19.5 \\
\hline & Oven at $100^{\circ}$ & $30 \mathrm{~min} .+$ at $50^{\circ}$ & 17.8 & 1.9 & 21.6 & 21.3 \\
\hline & $", \quad \quad$, & $60, \quad+50^{\circ}$ & 18.2 & 1.7 & 21.1 & 19.6 \\
\hline & $"$ & & 15.8 & 2.5 & 21.2 & 20.3 \\
\hline \multirow[t]{3}{*}{ Red clover leaves } & Vacuum at $40^{\circ}$ & & 7.2 & 1.4 & 9.2 & 31.7 \\
\hline & Oven at $65^{\circ}$ & & 7.4 & 3.2 & 9.4 & 31.8 \\
\hline &,$\quad 100^{\circ}$ & & 5.2 & 3.8 & 10.7 & 31.7 \\
\hline \multirow{4}{*}{$\begin{array}{l}\text { Calcifor silage of } \\
\text { grasses I }\end{array}$} & Vacuum at $40^{\circ}$ & & 0.7 & 6.2 & 29.0 & 11.6 \\
\hline & Oven at $100^{\circ}$ & $60 \mathrm{~min} .+$ at $50^{\circ}$ & 0.7 & 6.6 & 29.2 & 11.2 \\
\hline & $\Rightarrow \quad 65^{\circ}$ & & 0.4 & 6.5 & 28.0 & 11.5 \\
\hline & $100^{\circ}$ & & 0.3 & 7.9 & 29.6 & 11.8 \\
\hline
\end{tabular}

Table 2. Effect of temperature on thick layer drying. Figures are percentages of dry matter.

\begin{tabular}{|c|c|c|c|c|}
\hline Material & $\begin{array}{l}\text { Drying procedure } \\
\text { Temperature }{ }^{\circ} \mathrm{C}\end{array}$ & Sugars & $\begin{array}{l}\text { Crude } \\
\text { lignin }\end{array}$ & $\begin{array}{l}\text { Crude } \\
\text { fibre }\end{array}$ \\
\hline \multirow[t]{4}{*}{ Cabbage II } & Freeze drying & 49.2 & 0.6 & 11.2 \\
\hline & Vacuum at $40^{\circ}$ & 48.1 & 0.7 & 11.6 \\
\hline & Oven at $65^{\circ}$ & 22.0 & 0.9 & 15.3 \\
\hline &,$\quad 100^{\circ}$ & 9.0 & 6.1 & 17.3 \\
\hline \multirow[t]{4}{*}{ Swede II } & Freeze drying & 61.0 & 0.4 & 9.5 \\
\hline & Vacuum at $40^{\circ}$ & 61.6 & 0.4 & 9.5 \\
\hline & Oven at $65^{\circ}$ & 55.9 & 0.5 & 9.8 \\
\hline & $\Rightarrow \quad 100^{\circ}$ & 26.3 & 5.4 & 11.4 \\
\hline \multirow[t]{3}{*}{ Calcifor silage of grasses } & Vacuum at $40^{\circ}$ & 0.8 & 6.4 & 29.2 \\
\hline & Oven at $65^{\circ}$ & 0.1 & 7.4 & 29.0 \\
\hline & $\Rightarrow \quad 100^{\circ}$ & 0.1 & 9.1 & 29.9 \\
\hline \multirow[t]{3}{*}{ Dry hay } & Freeze drying & 9.5 & 7.2 & 31.7 \\
\hline & Vacuum at $40^{\circ}$ & 9.2 & 7.5 & 31.7 \\
\hline & Oven at $100^{\circ}$ & 6.8 & 8.2 & 32.3 \\
\hline
\end{tabular}


The main purpose of the experiments was to develop a method for drying a herbage sample in a simple oven without sugar losses. As can be seen from Table 1, this can be done in a rather simple way: the sample is first heated as a thin layer at $100^{\circ} \mathrm{C}$. 1 hour (without forced-draught) is appropriate for a juicy sample (swede, cabbage), whereas for thin-leafed samples (grass, clover) 30-60 minutes is sufficient. It is important to avoid full drying of the sample during this stage. The initial drying destroys the plant's own enzymes and microbes. The drying is then completed at a lower temperature to prevent the sugar losses. In this instance the final drying temperature was $50^{\circ} \mathrm{C}$. When the sample layer is about $1 \mathrm{~cm}$ in thickness (with loose grasses even thicker), this temperature does not affect the analytical results.

Tables 1 and 2 further indicate that the common drying method - oven at $65^{\circ} \mathrm{C}-$ causes minor sugar losses only, and does not affect the lignin and the fibre content provided that the drying is carried out as a thin layer. However, if the sample is dried at $4-5 \mathrm{~cm}$ thickness, considerably larger figures are obtained for both the crude lignin and crude fibre contents. A distinct difference is observable between the swede and cabbage: the erroneously performed drying has affected more strongly the cabbage than the swede, despite the fact that ground swede dries much more slowly than does loose chopped cabbage.

At $100^{\circ} \mathrm{C}$ the errors are strongly evident. This is especially true in respect of materials which have a high water content such as cabbage and swede. In the drying of dry hay the errors are rather small. In the case of roughage, no attention should be paid to small differences in the analytical data, since it is difficult to prepare quite homogeneous samples from grasses, the leaf and stem part of which differ greatly in composition.

Experiments with cow faeces. The effect of the layer-thickness was known at the beginning of the tests with cow faeces, which were accordingly dried at a fixed layer-thickness. The faeces samples originate from the indoor-feeding season and from cows that had received food rich in concentrates.

The results obtained (Table 3 ) indicate that the sample thickness does not affect the analytical figures when the drying is carried out in vacuum at 40 or $50^{\circ} \mathrm{C}$, whereas at

Table 3. Effect of temperature and layer thickness on the analysis results. Figures are percentages of dry matter.

\begin{tabular}{|c|c|c|c|c|}
\hline $\begin{array}{l}\text { Drying procedure } \\
\text { Temperature }{ }^{\circ} \mathrm{C}\end{array}$ & & $\begin{array}{l}\text { Crude } \\
\text { lignin }\end{array}$ & $\begin{array}{r}6.25 \times \mathrm{N} \\
\text { in cr.lignin }\end{array}$ & $\begin{array}{c}\text { Crude } \\
\text { fibre }\end{array}$ \\
\hline \multicolumn{5}{|l|}{ Cow faeces I } \\
\hline \multicolumn{2}{|c|}{ Vacuum at $40^{\circ}, 1 \mathrm{~cm}$ depth } & 12.8 & & \\
\hline$\Rightarrow, \quad, 5$ & $"$ & 12.5 & & \\
\hline $50^{\circ}, 1$ & , & 12.9 & & \\
\hline$, \quad, \quad 5$ & , & 12.5 & & \\
\hline \multicolumn{5}{|c|}{ Cow faeces II } \\
\hline \multicolumn{2}{|c|}{ Vacuum at $40^{\circ}, 1 \mathrm{~cm}$ depth } & 10.9 & 2.4 & 27.1 \\
\hline Oven at $65^{\circ}, 1$ & , & 11.6 & 2.6 & 27.2 \\
\hline,, 5 & $"$ & 13.8 & 3.5 & 28.4 \\
\hline $100^{\circ}, 1$ & 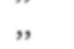 & 12.5 & 3.0 & 26.9 \\
\hline,, 5 & $"$ & 13.5 & 3.7 & 33.9 \\
\hline
\end{tabular}


$65^{\circ} \mathrm{C}$ the errors are evident particularly in respect of the lignin. At this temperature a slightly too high a percentage of lignin is arrived at even in thinlayer drying; for thicker layers the error is of the same magnitude as at a temperature of $100^{\circ} \mathrm{C}$. The error in the lignin-value is mainly related to nitrogenous substances; if a protein-correction is made $(6.25 \times \mathrm{N})$, the error due to the heat-drying is reduced. In the determination of the crude fibre, the temperature exercises a stronger influence than does the layer-thickness.

When the analytical data obtained from erroneously dried cabbage, swede and faeces samples are compared, it can be noted that distinct differences occur in the magnitude of the analytical errors, although the three samples do not differ very much in water content. The magnitude of the error must thus bear a relation to the composition of the dry matter.

The error accountable to the heat-drying originates in the socalled Maillard reaction (BRAVERman 1963), a reaction between the carbohydrates and proteins accelerated by high temperature and a high water content. The reduced digestibility of the proteins in foods dried at too high a temperature, for example in the artificially dried grasses, is attributable to the same reaction.

It seems that not even a high drying temperature is able to affect the figures for the crude protein obtained by the Kjeldahl method. At the most, these figures - as well as the ash-percentages - are slightly raised at $100^{\circ} \mathrm{C}$, implying that slight losses of the dry matter occur at $100^{\circ} \mathrm{C}$.

Experiments with pure mixtures. Previous findings (Salo 1965b) had already proved that the addition of an organic acid into a sugar solution causes the decomposition of sugars even at a rather low temperature. The present tests were carried out with a view to investigating whether the same procedure suffices to bring about errors in the residue determinations, or whether the presence of amino acids is required as well. The compositions of the mixtures and the analytical data obtained are given in Table 4. The following amino acids were used: glycine $(5 \%)$, aspartic acid $(3 \%)$ and glutamic acid $(2 \%)$. Water was added to the mixtures until a thick pulp resulted ( $\mathrm{I}$ and II $200 \mathrm{ml}$, III $150 \mathrm{ml} / 100 \mathrm{~g}$ of dry matter). The mass was dried either as a very thin layer $(0.5-1 \mathrm{~cm})$ or as a layer $4 \mathrm{~cm}$ in thickness.

Table 4. Effect of drying procedure on the analysis-results of pure compounds containing $60 \%-70 \%$ of water.

\begin{tabular}{|c|c|c|c|c|c|c|c|c|c|c|c|c|c|}
\hline \multirow{2}{*}{\multicolumn{4}{|c|}{$\begin{array}{l}\text { Dry matter composition } \\
\text { of compounds, } \%\end{array}$}} & \multirow{3}{*}{\multicolumn{4}{|c|}{$\begin{array}{r}\text { Drying procedure } \\
\text { Temperature }{ }^{\circ} \mathrm{C}\end{array}$}} & \multicolumn{6}{|c|}{$\%$ of dry matter } \\
\hline & & & & & & & & \multicolumn{3}{|c|}{ sugars } & \multicolumn{3}{|c|}{ crude lignin } \\
\hline & I & II & III & & & & & I & II & III & I & II & III \\
\hline Sucrose & 50 & & & Freez & ryin & & & 54.1 & 51.9 & 50.1 & 0.1 & 0.1 & 0.1 \\
\hline Fructose & & 50 & 50 & Vacu & at & $40^{\circ}, 1$ & lepth & 53.1 & 51.3 & 50.3 & 0.1 & 0.1 & 0.1 \\
\hline Starch & 5 & 5 & 5 & , & & 4 & , & & 51.5 & 50.0 & & 0.1 & 0.1 \\
\hline Agar-agar & 25 & 25 & 15 & Oven & at & $65^{\circ}, 1$ & , & 52.7 & 48.4 & 45.9 & 0.1 & 0.1 & 0.1 \\
\hline Filter paper & 10 & 10 & 10 & , & & , 4 & , & & 41.4 & 38.2 & & 0.2 & 0.2 \\
\hline Malic acid & 10 & & 10 & , & & $100^{\circ}, 1$ & , & 20.7 & 7.9 & 16.2 & 0.3 & 0.2 & 4.4 \\
\hline Citric acid & & 10 & & , & & , 4 & , & & 5.2 & 4.1 & & 0.7 & 20.0 \\
\hline Amino acids & & & 10 & & & & & & & & & & \\
\hline
\end{tabular}


The results presented in Table 4 indicate that the sugar losses are attributable to the high temperature and sample-acidity alone; the amino acids do not seem to affect the magnitude of the error. On the other hand, the magnitude of the error in the lignin and crude fibre content depends on both the carbohydrates and the amino acids. Although drying at $100^{\circ} \mathrm{C}$ also in the absence of amino acids brings about a slight increase in the percentage of lignin, the large errors do not manifest themselves unless the amino acids and carbohydrates are both present. Thus, on thick-layer drying at $100^{\circ} \mathrm{C}$, a $20 \%$ contens of crude lignin was obtained, although the mixture was free from lignin. This error becomes more pronounced on slow drying of a thick layer of substrate.

The crude lignin error relates to nitrogenous substances. However, only a part of the error can be eliminated by the application of the conventional protein correction $(6.25 \times \mathrm{N})$. In these tests, $1.0 \%$ and $4.8 \%$ of crude protein of crude lignin, respectively, were obtained for mixture III dried at $100^{\circ} \mathrm{C}$. The corresponding values for "pure lignin» were $3.4 \%$ and $15.8 \%$ of the dry matter, respectively.

The mixtures were analysed also for their crude fibre content, and a similar trend, although weaker, was noted also in this determination. Errors were evident only for samples from mixture III dried at $100^{\circ} \mathrm{C}$. In thin-layer drying, the magnitude of the error was of the order of a few percentage-units, whereas in thick-layer drying the crude fibre percentage was doubled, e.g. from 8.5 to 17 per cent.

\section{Su m mary}

The influence of erroneous drying methods on the analysis results was investigated. The test series included herbage and faeces samples, and pure mixtures. The samples were analysed for sugars, lignin, crude fibre and crude protein. The following results were noted:

Samples dried in a vacuum at $40^{\circ} \mathrm{C}$ yielded the same results as those treated by freeze drying. No attention need be paid to the sample thickness. From the technical point of view, vacuum drying is preferable to freeze drying.

Oven-drying gave good results when the following technique was used: The herbage sample is first heated as a thin layer at $100^{\circ} \mathrm{C}$ for $30-60 \mathrm{~min}$., depending on the water content. Final drying is carried out at $50^{\circ} \mathrm{C}$.

The conventional drying temperature, $65^{\circ} \mathrm{C}$, is too high. The thin-layer drying technique causes errors in the sugar content, the thick-layer drying also in the figures for lignin and crude fibre.

Between 50 and $100^{\circ} \mathrm{C}$, the thickness of the sample layer induces in many wet samples a larger error than does the high temperature.

Different materials react to heat-drying in different ways. The major factors are the water content and the composition of the dry matter.

The drying method does not affect the data for the crude protein, as determined by the Kjeldahl method.

The following facts were noted for the pure mixtures:

A high temperature is sufficient to cause sugar losses; proteins are not necessary.

A reaction between carbohydrates and amino acids brings about the drying error in the lignin and crude fibre results. High temperature and high water content magnifies 
the error. Application of a protein correction for the crude lignin eliminates only a part of the error introduced.

\title{
REFERENCES
}

Barthurst, N. O. \& Allison, R. M. 1949. The preparation of plant tissue for analysis. N.Z.J. Sci. Technol. Sect. B. 31: 1-14.

Braverman, J. S. B. 1963. Introduction to the biochemistry of foods. 336 p. Amsterdam/London/New York.

Davies, A. W., Evans, R. A. \& Evans, W. C. 1948. Studies on the biochemistry of pasture plants. 1. A new technique for the preparation and preservation of herbage samples. J. Brit. Grassl. Soc. 3: 153-158.

Horman, M. A. J. 1965. Microwave heating as an energy source for the pre drying of herbage samples. P1. Soil 23: 145-148.

Jones, D. I. H. \& Grifrith, G. 1968. Microwave drying of herbage. J. Brit. Grassl. Soc. 23: 202-205.

SALo, M-L. 1965a. Determination of carbohydrate fractions in animal foods and faeces. Acta Agr. Fenn. 105: 1-102.

»1965b. On the breakdown of sugars during the drying of plant samples and their subsequent dry storage. J. Sci. Agric. Soc. Finl. 37: 186-194.

van Soest, P. J. 1964. Symposium on nutrition and forage and pastures: new chemical procedures for evaluating forages. J. Animal Sci. 23: 838-845.

\section{SELOSTUS:}

\section{OHJEITA KASVINÄYTTEIDEN KUIVAAJILLE}

\author{
Maija-Lissa Salo ja Kaija Kotilainen
}

\section{Kotieläintieteen laitos, Helsingin yliopisto}

Liian korkeassa lämpötilassa ja vahvana kerroksena kuivatusta näytteestä saadaan liian alhaisia sokeri- ja liian korkeita ligniini- ja raakakuituprosentteja. Sokerihäviöihin riittää tietyn lämpötilan ylitys ja orgaaninen happo. Ligniinin ja kuidun virheitä aiheuttavat hiilihydraatit ja valkuaisaineet, jotka korkeassa lämpötilassa reagoidessaan muodostavat vaikealiukoisia yhdisteitä. Vesipitoisuuden lisäys (= kerroksen vahvuus) nostaa virhettä.

Seuraavilla kuivatustavoilla näitä virheitä voidaan välttää;

Kylmäkuivatus on luotettava, mutta kallis, heikkotehoinen, ja analyysitekniikan kannalta kuumakuivatusta hankalampi tapa.

Vakuumikuivatus on helpoin ja luotettavin kuumakuivatustapa. $40^{\circ}$ :ssa kuivaten ei mainittuihin kolmeen ryhmään tule virheitä eikä edes näytekerroksen vahvuuteen tarvitse kiinnittää huomiota. $50^{\circ}$ on jo joillekin materiaaleille liian korkea lämpötila.

Tavallista kuivauskaappia käytettäessä päästään hyvään tulokseen seuraavalla menetelmällä: Näytettä kuivataan ohuena kerroksena $100^{\circ}$ :ssa $30-60 \mathrm{~min}$. Se ei saa mennä kuivaksi. Käsittely tuhoaa entsyymit ja mikrobit. Kuivaus suoritetaan loppuun $50^{\circ}$ :ssa.

Tavanomainen $65^{\circ}$ on liian korkea lämpötila. Ohuena kerroksena kuivaten virhettä tulee vain sokereihin, paksuhkona kerroksena kuivattaessa myös ligniiniin ja raakakuituun.

$50^{\circ}-100^{\circ}$ välillä useimmilla korkean vesipitoisuuden omaavilla aineilla näytekerroksen vahvuus lisää virhettä enemmän kuin lämpötilan nousu.

Eri materiaalit reagoivat kuumakuivatuksessa eri tavoin. Vaikuttavia tekijöitä ovat sekä vesipitoisuus että kuiva-aineen koostumus. 